\title{
Preliminary results of winter savory (Satureja montana L.) cultivated under permeable mulch film in dry farming conditions of South Banat
}

\author{
Dragoja Radanović ${ }^{1}$, Ana Matković ${ }^{1}$, Rada Đurović-Pejčev ${ }^{2}$, Tatjana Marković ${ }^{1}$,

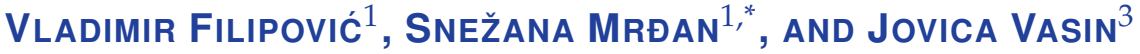 \\ ${ }^{1}$ Institute for Medicinal Plant Research "Dr. Josif Pančić”, Tadeuša Košćuška 1, 11000 Belgrade, Serbia \\ 2 Institute of Pesticides and Environmental Protection, Banatska 31b, 11080 Belgrade, Serbia \\ ${ }^{3}$ Institute of Field and Vegetable Crops, Maksima Gorkog 30, 21000 Novi Sad, Serbia \\ *Corresponding author: smrdjan@mocbilja.rs
}

Received: November 21, 2018

Accepted: December 10, 2018

Published on-line: December 20, 2018

Published: December 25, 2018

\begin{abstract}
The aim of study was to investigate development of perennial medicinal plant, Satureja montana L., cultivated in dry farming conditions of South Banat, Serbia, with use of black permeable mulch film. In the first two vegetations, the influence of fertilization and crop density on yields of the aboveground plant part (per plant and per $\mathrm{m}^{2}$ ) and on the content of total essential oil and its major constituents was observed. Overwintering survival, after late performed first harvest, and surviving ratio by the end of the second year of vegetation were $90.1 \%$ and $86.9 \%$, respectively. Ratio between fresh and dry biomass (2.4:1) was not affected by tested treatments. The yield per plant was affected by the treatments only in the second year. Higher crop density produced $25 \%$ higher yield, while organic fertilization variant yield was $19 \%$ higher. In both years, crop density did not show significant effect on yield per unit area, while in case of fertilization, this yield was higher in organic fertilization compared to mineral in the first and the second year, $7 \%$ and $19 \%$, respectively. The essential oil yields ranged from $0.8 \%$ to $0.9 \%$, with the major constituent thymol (48.3-69.4\%), followed by carvacrol, $p$ cymene and $\beta$-bisabolene. The essential oil yield did not depend on treatments, while the content of major constituents was significantly affected only by applied crop density.
\end{abstract}

Key words: $\quad$ winter savory; cultivation; mulch film; fertilization; crop density; herb yield; essential oil

http://dx.doi.org/10.5937/leksir1838051M

\section{INTRODUCTION}

Winter savory (Satureja montana L.) is a perennial plant species belonging to Lamiaceae family. It naturally grows in the subMediterranean area. Genus Satureja counts about 30 species out of which in Serbia only 9 may be found. Winter savory is a semi-evergreen subshrub growing to about $50 \mathrm{~cm}$ tall with the lanceolate leaves and pink to white flowers that attract bees. Leaves and stems of plant are used fresh and dry as a spice and in traditional medicine as tonics, carminative, astringent and expectorant (Rzepa et al., 2012). According to Stepanovic and Radanovic (2011) as a herbal tea, it is used in treating number of ailments. It's essential oil is used in food and in perfume industry alone or blended with other essential oils (Sefidkon et al., 2004).

According to Slavkovska et al. (2001) S. montana is confusing from the taxonomic point of view as its high variability is evident, within a single population polymorphism and especially in populations coming from distant habitats. Some studies indicate that composition and yield of its essential oil may be of different chemotypes due to different climatic conditions in which the plant may grow and also the stage of plant development (Milos et al., 2001; Damjanovic-Vratnica et al., 2011). According to literature data, the essential oil yield in different climatic conditions can range from 0.5 to $2.9 \%$ (Stepanovic and Radanovic, 2011; Sefidkon et al., 2004; Milos et al., 2001; Kišgeci, 2008). In climatic conditions of Serbia the essential oil yield use to be about 1.5\%, with carvacrol, thymol, linalool, $\gamma$ terpinene and $p$-cymene as major components (Stepanovic and Radanovic, 2011). Plantations with mulching films are usually established by planting well-developed seedlings. Nursery plants require care and various protection measures, especially against weeds in first years following their transplantation into the field (Altland et al., 2003). In order to avoid application of herbicides, alternative weed control methods are preferable. Physical methods, such as mulching, provide better conditions for cultivated crop as they reduce weeds and influence soil 
moisture, temperature and structure (Radanovic et al., 2016; Matković et al., 2015). In addition, dry farming conditions, which frequently include extreme environmental conditions (drought, high summer or low winter temperatures, strong wind, etc.) imply necessity to define appropriate cultivation measures which also reduce already observed luck of labor force (Radanovic et al., 2007). Investing in the application of mulches appears to be expensive at the beginning, but in the long-term proved to be effective, as it diminishes use of pesticides, irrigation and labor. The aim of this study was to test the efficacy of black "agrotextil" permeable film in dry farming conditions of South Banat, on the development of cultivated S. montana and to investigate how different fertilizers and applied crop density affect the crop yield and quality. In addition, crop density was estimated and monitored during the whole experiment.

\section{MATERIALS AND METHODS}

\subsection{Locality}

Field experiment was established in Pančevo $\left(44^{\circ} 52^{\prime} 20.0^{\prime \prime} \mathrm{N}\right.$, $\left.20^{\circ} 42^{\prime} 04.7^{\prime \prime} \mathrm{E}\right)$, South Banat, Serbia. The major climate type was temperate continental with annual precipitation of $621 \mathrm{~mm}$ and the average annual temperature of $11.4^{\circ} \mathrm{C}$. An important characteristic of the climate is southeast wind "Koshava". The precipitations and temperatures during two years of investigation are presented in Figure 1.

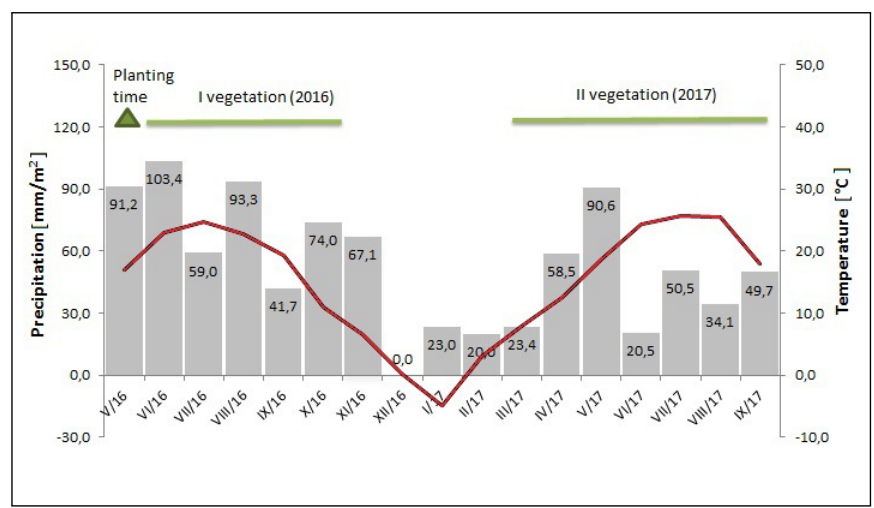

Fig. 1. Climatic conditions during two production years of S. montana L. in Pančevo, South Banat

The soil type was chernozem. Its main properties are given in Table 1.

\subsection{Nursery plants production}

The seeds of winter savory used in this experiment originate from seed collection of Institute for Medicinal Plants Research "Dr Josif Pančić", Belgrade, Serbia. Nursery plants have been produced in greenhouse, in pots filled with $0.4 \mathrm{~L}$ peat sowing substrate (Gramoflor). Production of nursery plants started in February, 2016 and plants were kept in greenhouse until planting.

\subsection{Field experiment}

The field trial has been established on $28^{\text {th }}$ May 2016 at experimental fields in Pančevo. Two types of fertilizers were applied prior to the soil tilling. In the first year as a mineral fertilizers ammonium nitrate $(34 \% \mathrm{~N})$ was applied in a dose of $300 \mathrm{~kg} / \mathrm{ha}$, and phosphorus-potassium mineral fertilizer (PK 16:32) in dose of $750 \mathrm{~kg} / \mathrm{ha}$, which together accounted $100 \mathrm{~kg} / \mathrm{ha}$ of $\mathrm{N}, 120 \mathrm{~kg} / \mathrm{ha}$ of $\mathrm{P}_{2} \mathrm{O}_{5}$ and $270 \mathrm{~kg} / \mathrm{ha}$ of $\mathrm{K}_{2} \mathrm{O}$ of applied macronutrient. In May 2017, the mineral plot was additionally fertilized with KAN $(27 \% \mathrm{~N})$ in dose of $200 \mathrm{~kg} / \mathrm{ha}$. The organic fertilizer was compost (with total content of NPK
$=1.4: 0.5: 1.4 \%$ ) produced in production unit of the Institute for Medicinal Plant Research "Dr Josif Pančić", Pančevo. In the first production year, compost was applied in a dose of $20 \mathrm{t} / \mathrm{ha}$ and therefore calculated values of nutrients were $280 \mathrm{~kg} / \mathrm{ha}$ of $\mathrm{N}, 100 \mathrm{~kg} / \mathrm{ha}$ of $\mathrm{P}_{2} \mathrm{O}_{5}$ and $270 \mathrm{~kg} / \mathrm{ha}$ of $\mathrm{K}_{2} \mathrm{O}$. In May 2017 the organic plot was additionally fertilized with liquid organic fertilizer BioGrow (NPK4:6:3) in dose of $5 \mathrm{~L} / \mathrm{h}$. Following the application of fertilizers, $1 \mathrm{~mm}$ thick black "agrotextil" film was inserted over subsequently trenched soil, with prepared holes for nursery plants in accordance to tested crop density (3.6 and 5 plants $/ \mathrm{m}^{2}$ ). The experimental design was twofactor block design with four replications. At each fertilization plot two different density patterns were applied. The rows (each with 9 plants) were replications, while the independent variables were fertilizers (levels: mineral and organic) and crop density (levels: 5 and 3.6 plants $/ \mathrm{m}^{2}$ ). The plots were arranged according to applied fertilizers. Each fertilization plot had two different density patterns. Size of one plot was $17.1 \mathrm{~m}^{2}(3.8 \mathrm{~m} \times 4.5 \mathrm{~m})$.

\subsection{Field measurements}

Following transplantation of nursery plants into the field, number of adopted plants was counted prior to harvest, and adaptation was expressed in percentages (AP \%). Winter savory was harvested at the stage of flowering. As transplantation of nursery plants was performed at the end of May, stage of flowering occurred in October with harvest carried out in 28th October, 2016. In the second production year, as vegetation season started in April thus stage of flowering occurred in September with harvest performed on 15th September, 2017. Since the first harvest was late in October, only four plants from each row in each plot were harvested. The remaining plants were used to estimate the overwintering and regeneration of harvested plants (OWR \%); for calculation of this percentage, the number of live plants in the spring (22 March, 2017) was compared to the number of those from the first harvest. Also, the number of remaining plants was counted prior to harvest in the second production year and expressed in percentages (RP \%). In the second harvest, all plants were harvested. For each plant fresh and dry biomass was measured (yield/single plant) and moisture loss upon drying calculated. Also, dry biomass of the aboveground plant part was calculated in order to present it as a yield/unit area (yield $/ \mathrm{m}^{2}$ ). Data were statistically processed by analysis of variance (ANOVA) in STATISTICA 7.0. Multiple comparisons were performed using LSD test to detect significant differences between the arithmetic means of yields $(\mathrm{P}<0.05)$.

\subsection{Herb quality estimation}

For quality assessment of produced herbal material, which included content of essential oil and its major constituents, 12 samples (repetitions) were taken from the middle rows of each plot, only in the second production year.

\subsubsection{Extraction of essential oil}

The air-dried plant material of $S$. montana was submitted to distillation for $2 \mathrm{~h}$ in a Clevenger type apparatus according to Procedure I of the Ph. Jug. IV (1984). The plant material was previously milled (M-20, IKA Universal mill) and $20 \mathrm{~g}$ of it was placed in a round bottom flask filled with $400 \mathrm{~mL}$ of water. The essential oils were dried over anhydrous sodium sulfate and stored in tightly closed dark vials at $4^{\circ} \mathrm{C}$ until further analysis.

\subsubsection{Essential oil analysis}

Identification of essential oil constituents was performed by Gas chromatography-Mass spectrometer (GC/MS, Varian CP$3800 /$ Saturn 2200) equipped with split/splitless injector and DB-5MS column ( $30 \mathrm{~m} \times 0.25 \mathrm{~mm}$, film of $0.25 \mathrm{~mm}$ thickness), 
Table 1. Chemical properties and clay content of the arable soil layer $(0-30 \mathrm{~cm})$

\begin{tabular}{|c|c|c|c|c|c|c|c|c|}
\hline \multirow{3}{*}{ Soil type } & \multicolumn{2}{|c|}{$\mathrm{pH}$} & \multirow[b]{2}{*}{$\mathrm{CaCO}_{3}$} & \multirow[b]{2}{*}{ Humus } & \multirow[b]{2}{*}{ Total N } & \multicolumn{2}{|c|}{$\mathrm{Al}$-method } & \multirow[b]{2}{*}{ Clay content } \\
\hline & in $\mathrm{H}_{2} \mathrm{O}$ & in $\mathrm{KCl}$ & & & & $\mathrm{P}_{2} \mathrm{O}_{5}$ & $\mathrm{~K}_{2} \mathrm{O}$ & \\
\hline & & & {$[\%]$} & {$[\%]$} & {$[\%]$} & {$[\mathrm{mg} / \mathrm{kg}]$} & {$[\mathrm{mg} / \mathrm{kg}]$} & {$[\%]$} \\
\hline Chernozem & 7.11 & 5.88 & 0.42 & 3.51 & 0.24 & 73 & 445 & 42.36 \\
\hline
\end{tabular}

using Wiley 7.0 library of mass spectra and by comparison of the obtained retention indices (RI) with the literature data (Adams, 2007). The hexane solution of the essential oil $(1 \mathrm{~mL}$, $1 \%$ solution) was injected in the split-mode (1:20) at injector, ion-trap and transfer lines temperatures of 250, 250 and 280 ${ }^{\circ} \mathrm{C}$, respectively. The flow rate of helium as a gas carrier, was 1 $\mathrm{mL} / \mathrm{min}$. The column temperature was linearly programmed from 50 to $250{ }^{\circ} \mathrm{C}$ at a heating rate of $4{ }^{\circ} \mathrm{C}$ and holding at $250^{\circ} \mathrm{C}$ (10 $\left.\mathrm{min}\right)$. Quantitative analysis was performed using a Gas-chromatography (GC, Agilent 7890A) equipped with split/splitless injector, HP-5 column $(30 \mathrm{~m} \times 0.32 \mathrm{~mm}$, film of $0.25 \mathrm{~mm}$ thickness) and a flame ionization detector (FID). The method of normalization was used for the representation of individual oil components presented in chromatograms after eliminating the solvent peak. The hexane solution of the essential oil ( $1 \mathrm{~mL}, 1 \%$ solution) was injected in the splitmode (1:20), at temperatures of the injector and detector of 250 and $3000{ }^{\circ} \mathrm{C}$, respectively, at a flow rate of hydrogen as a carrier gas of $1 \mathrm{~mL}$ permin. The temperature program of the column was the same as in the case of GC/MS analysis. In order to determine the RI values, a mixture of n-alkanes $\left(\mathrm{C}_{6}-\mathrm{C}_{28}\right)$ was analyzed by both GC-FID and GC-MS under identical conditions as the essential oils. Essential oil data were statistically processed by analysis of variance (ANOVA) in STATISTICA 7.0.

\section{RESULTS AND DISCUSSION}

\subsection{Crop density}

Crop density, estimated through the number of adopted plants $(\mathrm{AP} \%)$ in the first production year, the number of overwintering and successfully regenerated plants (OWR \%) and the number of remaining plants at the end of second production year $(\mathrm{RP} \%)$ is presented in Figure 2.

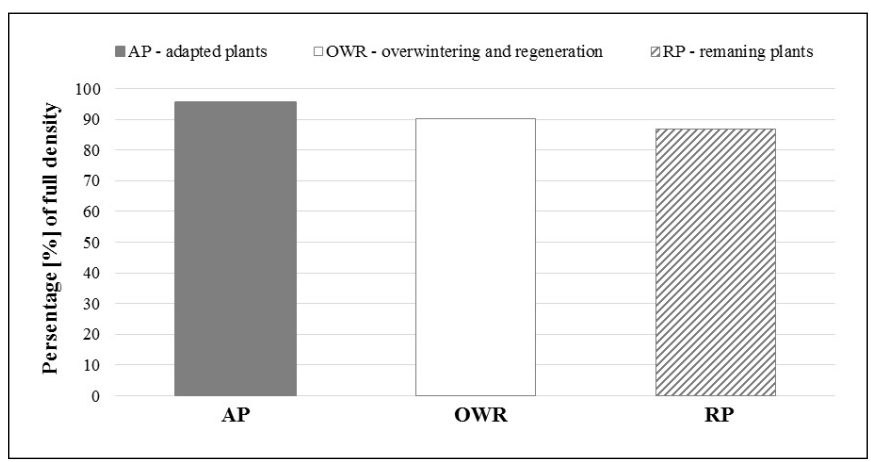

Fig. 2. Crop density of winter savory in the first and second year of the experiment

From planting to harvest, $4.6 \%$ plants decayed in the first year $(\mathrm{AP} \%)$. Since the first harvest was quite later then common for majority of medicinal plants, as it further may cause losses due to the freezing during winter, plants overwintering and regeneration was estimated. For instance, in the same climatic conditions, following the late autumn harvest, 50 -
$90 \%$ loss was recorded for common thyme due its freezing during winter (Stepanović B. - personal communication). In our study, loss was $4.7 \%$ in harvested part of plots, while in the non-harvested one was $6.0 \%$; it accounts for $5.3 \%$ of the total loss per plot (Figure 2, OWR \%). However, differences in losses between harvested and non-harvested plot parts and also within the treatments were not significant, as the treatments and the late harvest did not affect the OWR. The total loss per plot following the period of relatively cold winter without snow cover (Figure 2), shows that winter savory successfully survived winter in the temperate continental climate conditions of South Banat, regardless its quite late harvest. Reduction in number of winter savory plants during first two production years also proved not to depend on treatments. At the beginning of the second vegetation, $90.1 \%$ of total number of plants was observed. Even though further loss of 3.2\% was observed by the end of second year of production (Figure 2, $\mathrm{RP} \%$ ), it was not due to extreme environmental conditions but associated to other factors (pest, disease etc.).

\subsection{Dry biomass yield}

The influence of crop density and fertilization on S. montana yield/single plant and yield/unit area is presented in Table 2.

\subsubsection{Yield per single plant}

Applied treatments had no significant effect on yield/single plant in first production year as multiple comparisons between the arithmetic means of yields didn't show differences (Table 2). This data suggests that the amount of nutrients applied through both fertilization models was sufficient for the balanced development of plants during first growing season. Likewise, the space for growing of tested density was sufficient in providing smooth, uniform development of plants through the first vegetation. Previously mentioned was confirmed by visual observation as well. All plants were grown apart from each other, without touching the side branches (Figure 3).

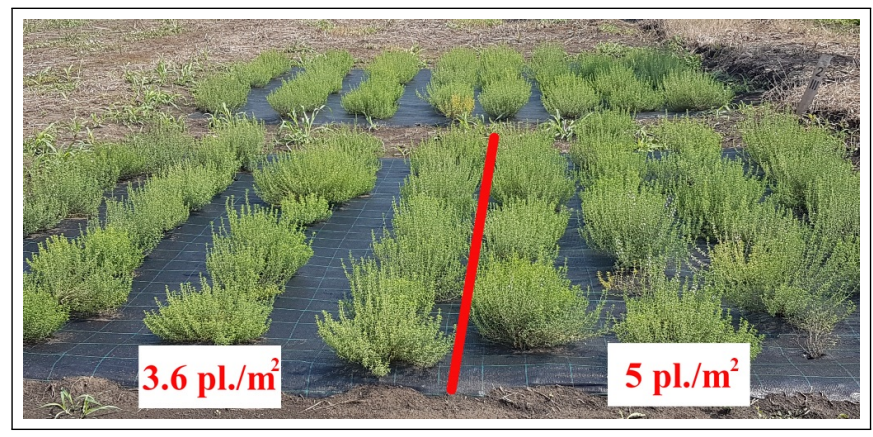

Fig. 3. Winter savory on mulch film in tested crop density, during the first vegetation (August, 2016)

In other studies is also explained how plants, in conditions where there is no competition for available nutrients in soil and light energy, have increased vegetative growth (Shalaby et al., 1997; Hussein et al., 2006). Like in our case, in the first 
Table 2. Comparative presentation of average herb yields of single $S$. montana plants and yield per unit area, with regard to crop density and fertilization models in two experimental years

\begin{tabular}{|c|c|c|c|c|c|}
\hline \multirow[b]{2}{*}{ Crop density } & \multirow[b]{2}{*}{ Fertilization } & \multicolumn{2}{|c|}{ Single plant yield } & \multicolumn{2}{|c|}{ Yield per area } \\
\hline & & First year ${ }^{\mathrm{a}}$ & Second year & First year & Second year \\
\hline [plants $/ \mathrm{m}^{2}$ ] & & [g/plant] & [g/plant] & {$\left[\mathrm{g} / \mathrm{m}^{2}\right]$} & {$\left[\mathrm{g} / \mathrm{m}^{2}\right]$} \\
\hline \multirow[t]{2}{*}{5} & Mineral & $72.5 \pm 10.4$ & $151.1 \pm 21.6 \mathrm{~b}$ & $300.0 \pm 98.8$ & $755.3 \pm 108.2 \mathrm{ab}$ \\
\hline & Organic & $80.9 \pm 15.0$ & $178.5 \pm 33.2 \mathrm{~b}$ & $359.4 \pm 90.5$ & $892.3 \pm 68.5 \mathrm{a}$ \\
\hline \multirow[t]{2}{*}{3.6} & Mineral & $81.4 \pm 21.1$ & $186.0 \pm 26.5 \mathrm{ab}$ & $293.0 \pm 76.0$ & $669.6 \pm 95.6 \mathrm{~b}$ \\
\hline & Organic & $80.9 \pm 24.9$ & $221.9 \pm 28.0 \mathrm{a}$ & $274.5 \pm 100.7$ & $799.0 \pm 100.7 \mathrm{ab}$ \\
\hline
\end{tabular}

${ }^{a}$ Values are presented as means \pm standard deviation. Values with the same letter in each column showed no statistically significant difference $(\mathrm{P}<0.05)$; Statistical analysis was based on a one-way ANOVA and LSD tests.

year plants are not completely formed and have enough space for grow. Thus, tested density didn't make the effect that showed a difference in impact on yield/single plant. Applied treatments had significant effect on yield $(\mathrm{P}<0.05)$ in second year and multiple comparisons between the arithmetic means of yields showed differences in fertilization models and within organic fertilization model. Also, significant differences were noticed in tested density (Table 2). In the second year, with further growth of plants, larger plants were formed in lower crop density, density of 3.6 plants $/ \mathrm{m}^{2}$, compared to plants grown in higher crop density, density of 5 plants $/ \mathrm{m}^{2}$. Therefore, winter savory in the second year may occupy area greater than $0.2 \mathrm{~m}^{2}$. Before the harvest in September, in the second year, it was noticed that the plants, grown in higher crop density, were touching each other with branches throughout its whole periphery. While plants, grown in lower crop density, were touching only within the rows and not between the rows, as a result of higher mid-row spacing $(70 \mathrm{~cm})$ (Figure 4). Plants of winter savory, grown in lower crop density, produced in average $25 \%$ higher yield per plant in the second year, compared to plants grown in higher crop density (Table 2).

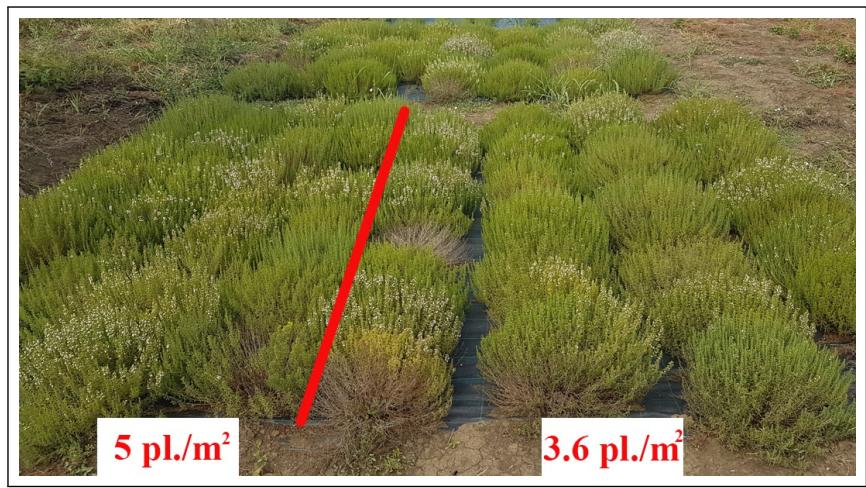

Fig. 4. Winter savory on mulch film in tested crop density, during the second vegetation (August, 2017)

In correspondence with our results, increases in fresh and dry yield/single plant due to a wider spacing was already reported for some medicinal crops, including lemon balm (Shalaby et al., 1993), purple coneflower (Shalaby et al., 1997) and dragonhead (Hussein et al., 2006), but also in some horticultural plants, such as tuberose (Khalaj et al., 2012).

Applied fertilization models in second year have also been found to affect the yield/single plant. In the organic fertilizer model yield/single plant was $200.2 \mathrm{~g} /$ plant, while in the mineral was $168.5 \mathrm{~g}$ / plant. Therefore $19 \%$ higher yield was achieved in the organic fertilizer model compared to mineral (Figure 5). Greater influence of organic fertilization on plant

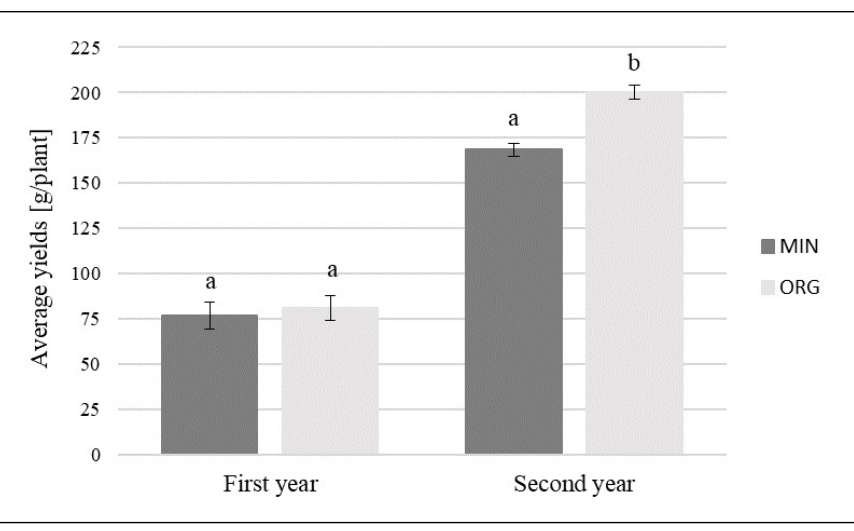

Fig. 5. Comparative presentation of average yields of $S$. montana [g/plant] with regard to fertilization models in two experimental years; MIN - mineral fertilizer; ORG - organic fertilizer; Error bars denote standard deviation; means followed by the same letter in same year are not significantly different at $\mathrm{P}<0.05$

growth compared to mineral can be explained by the mineralization of organic fertilizer that becomes intensive in the second year after application (Ubavić and Vojin, 2005). It can be assumed that moisture preserved under the black mulch film, only further amplified mineralization in dry farming conditions, as moister is an important factor for microbial mineralization of organic matter in soil and movement of nutrients towards the root (Mengel and Kirkby, 2001). In the second year, the summer period was characterized with lack of precipitation (Figure 1), thus positive effects of mulch film in preserving soil moisture was recognized. In these conditions, plants became more supplied with nutrients in the organic fertilizer model than in mineral one, which resulted in better development of these plants. Used black "agrotextil" permeable film proved to be effective in preserving moisture and also in controlling weeds. Studies done on peppermint confirmed effectiveness of black "agrotextil" permeable film on yield and weed reduction (Matković et al., 2015). Positive effect in use of plastic mulch films on medicinal crops was reported in other studies conducted in our country as well (Radanovic et al., 2007; 2016). Loss of moisture upon drying of harvested aboveground parts of S. montana was estimated by the ratio between fresh and dry herbal material; it ranged 2.4-2.9:1 in the first and 2.0-2.1 in the second experimental year, and proved not to be depended on applied treatments. The average ratio 2.4:1 appeared to be quite lower then a number of other perennial medicinal plants (thyme, common yarrow, hyssop, plantain or St. John's worth), which according to Stepanovic and Radanovic (2011) ranged from 3:1 to 10:1. 


\subsubsection{Yield per unit area}

Greater number of plants $/ \mathrm{m}^{2}$ in higher crop density compensate for the decreased yield of the individual plants, which led to statistically identical yield $/ \mathrm{m}^{2}$ for tested density in both growing seasons (Table 2) with a slightly higher yield at crop density of 5 plants $/ \mathrm{m}^{2}$, but without statistical significance. Other investigations also point out how narrower spacing results in higher yields of herb per unit area (Shalaby et al., 1993; Saglam et al., 2004; Balyan and Sobti, 1990; Arabaci and Bayram, 2004). The influence on fertilization on S. montana herb yield is presented in Figure 6 .

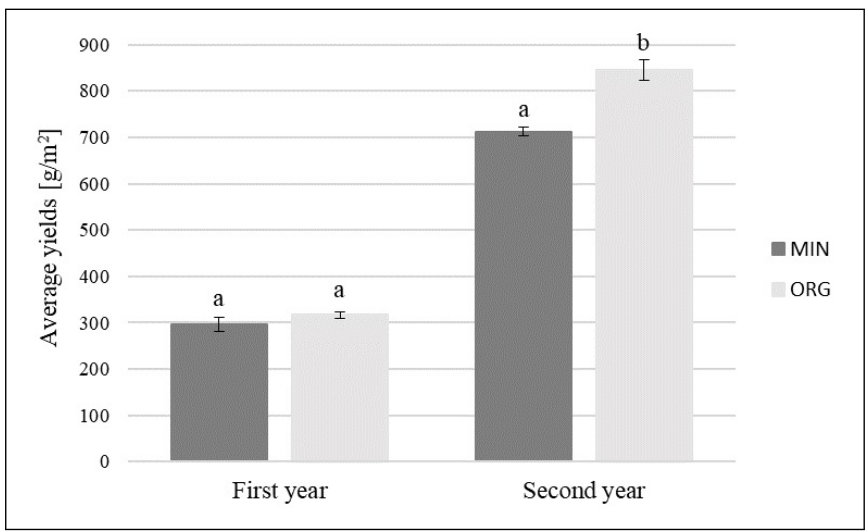

Fig. 6. Comparative presentation of average yields of S. montana $\left[\mathrm{g} / \mathrm{m}^{2}\right]$ with regard to fertilization models in two experimental years; MIN - mineral fertilizer; ORG - organic fertilizer; Error bars denote standard deviation; means followed by the same letter in same year are not significantly different at $\mathrm{P}<0.05$

In second year, fertilizer models showed significant differences in achieved yields $(\mathrm{P}<0.05)$, which was confirmed by multiple comparisons between the arithmetic means of yields in different models of fertilization. The organic-fertilized plants gave higher yields in both years $\left(316.9 \mathrm{~g} / \mathrm{m}^{2}\right.$ and 845.6 $\mathrm{g} / \mathrm{m}^{2}$, respectively) compared to mineral fertilized plants ( $296.5 \mathrm{~g} / \mathrm{m}^{2}$ and $712.5 \mathrm{~g} / \mathrm{m}^{2}$, respectively) (Figure 6). As so, in second year, yield in organic-fertilized plants was higher with statistical significance, while in first year was higher, but without statistical significance (19\% and $7 \%$, respectively). The lowest yields were obtained with lower crop density during the first year in both used fertilization models while in the second year, the lowest yield was noticed only in the mineral fertilization model for crop density 3.6 plants $/ \mathrm{m}^{2}$ (Table 2). This shows that application of mineral fertilizers in plantation probably can't provide a satisfactory level of nutrition in winter savory for maximum herb yield. The organic fertilization, in this respect, provides a better long-term effect.

\subsection{Essential oil yield and composition}

The essential oil yields (\%, v/w) and contents of major constituents, contributing to the essential oil with $>1 \%$, are presented in Table 3. Analysis of the examined samples of $S$. montana essential oil showed that the 10 major identified constituents accounted 90.3 to $95.3 \%(\mathrm{v} / \mathrm{w})$ of total essential oil content.

Several studies conducted with $S$. montana revealed that it's essential oil may be of different chemotypes and that the essential oil yield and composition may depend on several factors. Damjanovic-Vratnica et al. (2011) observed that essential oil yield in dry leaves of $S$. montana wild collected from the central part of Montenegro, decreases with development of flowering stage; it was $1.9 \%$ prior to and $1.1 \%$ during the flowering stage. Similarly, Milos et al. (2001) reported for $S$. montana wild collected from different localities in Dalmatia, Croatia, in stage prior to, during and after flowering, the es- sential oil yield ranged $1.6 \%-1.9 \%, 1.2 \%-1.8 \%$, and $0.7 \%$, respectively. The essential oil yield in our study was evaluated only at harvest, conducted at the stage of full flowering; it ranged from $0.8 \%$ to $0.9 \%$. Analysis of variance showed that tested independent variables, fertilizers and crop density, had no significant effect on essential oil yield. The major constituent of in all our S. montana essential oil samples was thymol $(48.3 \%-69.4 \%)$, while carvacrol $(6.9$ to $15.3 \%)$ and p-cymene $(3,6-13.1 \%)$ were the second and the third most dominant oil constituents. The latter two constituents were reported to be the major in other S. montana oils originating from the neighboring region. Bezić et al. (2005) reported that essential oil from Biokovo, Croatia was dominant in carvacrol $(45.7 \%)$ with low thymol content $(3.9 \%)$, while Slavkovska et al. (1997) in essential oil from the gorge of river Beli Rzav reported richness in p-cymene $(47.2 \%)$. In our country, recently Elgndi et al. (2017) also reported richness in carvacrol (57.1\%) in oil of S. montana cultivated in Pannonia lowland (Bački Petrovac, Serbia). Though according to the most literature data the major compound of winter savory's essential oil is carvacrol, similar to our results, some studies done in surrounding countries also reported thymol as a major compound. Thus, in samples from Trebinje (Bosnia and Herzegovina) Ćavar et al. (2008) found $31.7 \%$ thymol and $23.3 \%$ of carvacrol, Mastelić and Jerković (2003) in samples from Sinj (Croatia) reported $30.9 \%$ of thymol and $3.8 \%$ of carvacrol, while Bezbradica et al. (2005) from Žabljak (Montenegro) reported 33.4\% thymol and $28.8 \%$ p-cymene. In addition, Damjanovic-Vratnica et al. (2011) observed variability in composition of essential oil of $S$. montana wild collected in central part of Montenegro, depending on time of harvest; before flowering content of thymol was $37.4 \%$ and the second major constituent was carvacrol, $15.5 \%$, while in the full flowering stage, thymol was $27.7 \%$, but the second constituent was $\gamma$-terpinene, $8.7 \%$. Mihajilov-Krstev et al. (2014) in samples collected from Montenegro, reported differences in essential oil composition depending on altitude; contents of thymol and carvacrol were the highest at the lowest examined altitude (100 m a.s.l, near the Budva city), 24.7\% and $15.2 \%$, respectively. Difference in chemical composition of this oil further suggest that geo-climatic parameters of locality where this plant species is cultivated might affect content of the major oil constituents, as there were apparent differences in available literature data. Analysis of variance (ANOVA) showed that significant difference $(\mathrm{p}<0.001)$ occurred within the content of essential oil constituents and in interaction constituent $x$ density (Table 3), while other treatments, beside density, didn't affect significantly content of oil constituents. The most dominant constituent, thymol, appeared in higher content in the higher crop density regardless applied fertilization model. The second major constituent, carvacrol, was higher in lower crop density, in mineral fertilization model, while the third constituent, p-cymene, was also higher in lower crop density, but only in organic fertilization model, while in mineral model showed no deference in content regardless of density. On content of $\beta$-bisabolene, neither of applied treatments showed effect, although it was slightly higher in organic fertilization model than in mineral model (Table 3).

\section{CONCLUSION}

Preliminary results of the first two production years showed that winter savory can be successfully grown on mulch in dry farming conditions of temperate continental climate of South Banat. According to obtained results, better yields were archived with application of organic fertilizer; in circumstances where the surface application of fertilizers is no more possible following the mulch setting, slow release of organic fertilizer applied in an appropriate single-dose, definitely provide better nutritional conditions for cultivated crop. 
Table 3. Yield of essential oil in above-ground plant part of $S$. montana and contribution of major oil constituents to total oil, with regard to crop density and fertilization models at the end of second production year

\begin{tabular}{|c|c|c|c|c|c|}
\hline \multirow[b]{4}{*}{ Constituents } & \multirow[b]{4}{*}{$\mathrm{RI}^{\mathrm{a}}$} & \multicolumn{4}{|c|}{ Fertilization/Density } \\
\hline & & \multicolumn{2}{|c|}{ Mineral } & \multicolumn{2}{|c|}{ Organic } \\
\hline & & $5 \mathrm{pl} . / \mathrm{m}^{2}$ & $3.6 \mathrm{pl} . / \mathrm{m}^{2}$ & $5 \mathrm{pl} . / \mathrm{m}^{2}$ & $3.6 \mathrm{pl} . / \mathrm{m}^{2}$ \\
\hline & & {$[\% \mathrm{~m} / \mathrm{m}]$} & {$[\% \mathrm{~m} / \mathrm{m}]$} & {$[\% \mathrm{~m} / \mathrm{m}]$} & {$[\% \mathrm{~m} / \mathrm{m}]$} \\
\hline$p$-Cymene & 1021 & $7.7 \pm 2.6$ & $7.5 \pm 4.9$ & $4.7 \pm 1.8$ & $9.6 \pm 1.0$ \\
\hline$\gamma$-Terpinene & 1055 & $1.0 \pm 1.2$ & $1.8 \pm 2.0$ & $0.4 \pm 0.3$ & $1.7 \pm 1.5$ \\
\hline Borneol & 1164 & $1.8 \pm 0.3$ & $1.9 \pm 0.1$ & $2.1 \pm 0.2$ & $1.8 \pm 0.2$ \\
\hline Terpinen-4-ol & 1175 & $0.9 \pm 0.1$ & $0.8 \pm 0.1$ & $0.8 \pm 0.1$ & $1.0 \pm 0.1$ \\
\hline Carvacrol, methyl ether & 1240 & $0.6 \pm 0.7$ & $0.6 \pm 0.4$ & $0.4 \pm 0.4$ & $0.5 \pm 0.3$ \\
\hline Thymol & 1291 & $65.2 \pm 2.7$ & $59.4 \pm 9.6$ & $66.0 \pm 4.4$ & $58.4 \pm 2.3$ \\
\hline Carvacrol & 1298 & $7.6 \pm 0.6$ & $13.0 \pm 2.7$ & $10.3 \pm 1.6$ & $9.6 \pm 0.6$ \\
\hline trans-Caryophyllene & 1418 & $1.3 \pm 0.2$ & $1.2 \pm 0.0$ & $1.6 \pm 0.3$ & $1.4 \pm 0.1$ \\
\hline$\beta$-Bisabolene & 1504 & $4.5 \pm 0.5$ & $5.0 \pm 0.7$ & $5.2 \pm 0.2$ & $5.3 \pm 0.7$ \\
\hline Caryophyllene oxide & 1584 & $1.6 \pm 0.2$ & $1.2 \pm 0.1$ & $1.8 \pm 0.5$ & $1.3 \pm 0.2$ \\
\hline Total & & $92.0 \pm 0.3$ & $92.2 \pm 2.1$ & $93.2 \pm 2.1$ & $90.6 \pm 0.3$ \\
\hline EO yield [\%v/w] & & $0.8 \pm 0.0$ & $0.8 \pm 0.1$ & $0.8 \pm 0.2$ & $0.9 \pm 0.1$ \\
\hline
\end{tabular}

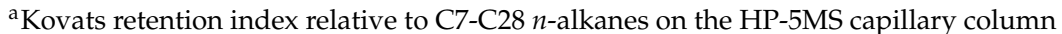

This could also be quite encouraging for further implementation of organic agriculture in medicinal crop production. The crop density of 5 plants $/ \mathrm{m}^{2}$ compensate lower yield per plant by higher yields per unit area. However, though differences were not statistically confirmed in the second production year, the yield in denser establishment was slightly higher, suggesting trend of increase of yields per unit area in further years, yet to be confirmed. In addition, the major constituent of in our S. montana essential oil samples was thymol and denser crop establishment positively influenced content of thymol. However, treatments did not affect total essential oil content. As $S$. montana is perennial crop, further research will continue with monitoring the influence of applied treatments in following 2-3 production years, in attempt to make an improvement of its production features, the yield and content and quality of essential oil.

\section{ACKNOWLEDGMENTS}

Acknowledgment.This study was supported by the Ministry of Education, Science and Technological Development of the Republic of Serbia; the projects III46013, III46008, TR31072 and TR31043.

\section{REFERENCES}

Adams, R. P. (2007). Identification of Essential Oil Components by Gas Chromatography/Mass Spectrometry, Allured Publishing Corporation, Illinois.

Altland, J. E., Gilliam, C. H. and Wehtje, G. (2003). Weed Control in Field Nurseries, HortTechnology 13(1): 6.

Arabaci, O. and Bayram, E. (2004). The effect of nitrogen fertilization and different plant densities on some agronomic and technologic characteristic of Ocimum basilicum l. (basil)., Journal of Agronomy 3(4): 255-262.
Ćavar, S., Maksimović, M., Šolić, M. E., Jerković-Mujkić, A. and Bešta, R. (2008). Chemical composition and antioxidant and antimicrobial activity of two Satureja essential oils, Food Chemistry 111(3): 648-653.

Balyan, S. and Sobti, S. (1990). Effect of inter and intra row spacing on growth, yield and eugenol content in Ocimum gratissimum linn (var. Clocimum), Indian Perfumer 34(3): 217224

Bezbradica, D. I., Tomovic, J. M., Vukasinovic, M. S., SilerMarinkovic, S. and Ristic, M. M. (2005). Composition and Antimicrobial Activity of Essential Oil of Satureja montana L. Collected in Serbia and Montenegro, Journal of Essential Oil Research 17(4): 462-465.

Bezić, N., Skočibušić, M. and Dunkić, V. (2005). Phytochemical composition and antimicrobial activity of Satureja montana L. and Satureja cuneifolia Ten. essential oils, Acta Botanica Croatica 64(2): 313-322.

Damjanovic-Vratnica, B., Perovic, A., Sukovic, D. and Perovic, S. (2011). Effect of vegetation cycle on chemical content and antibacterial activity of Satureja montana L., Archives of Biological Sciences 63(4): 1173-1179.

Elgndi, M. A., Filip, S., Pavlić, B., Vladić, J., Stanojković, T., Žižak, e. and Zeković, Z. (2017). Antioxidative and cytotoxic activity of essential oils and extracts of Satureja montana L., Coriandrum sativum L. and Ocimum basilicum L. obtained by supercritical fluid extraction, The Journal of Supercritical Fluids 128: 128-137.

Hussein, M., El-Sherbeny, S., Khalil, M., Naguib, N. and Aly, S. (2006). Growth characters and chemical constituents of Dracocephalum moldavica L. plants in relation to compost fertilizer and planting distance, Scientia Horticulturae 108(3): 322-331. 
Khalaj, M. A., Edrisi, B. and Amiri, M. (2012). Effect of Nitrogen and Plant Spacing on Nutrients Uptake, Yield and Growth of Tuberose (Polianthes tuberosa L.), Journal of Ornamental and Horticultural Plants 2(1): 11.

Kišgeci, J. (2008). Lekovite i aromatične biljke, Partenon, Beograd.

Mastelić, J. and Jerković, I. (2003). Gas chromatography-mass spectrometry analysis of free and glycoconjugated aroma compounds of seasonally collected Satureja montana L., Food Chemistry 80(1): 135-140.

Matković, A., Božić, D., Filipović, V., Radanović, D., Vrbničanin, S. and Marković, T. (2015). Mulching as a physical weed control method applicable in medicinal plants cultivations, Lekovite sirovine 35: 37-51.

Mengel, K. and Kirkby, E. A. (2001). Principles of Plant Nutrition, 5 edn, Springer Netherlands.

Mihajilov-Krstev, T., Radnović, D., Kitić, D., Jovanović, V. S., Mitić, V., Stojanović-Radić, Z. and Zlatković, B. (2014). Chemical composition, antimicrobial, antioxidative and anticholinesterase activity of Satureja montana L. ssp montana essential oil, Central European Journal of Biology 9(7): 668-677.

Milos, M., Radonic, A., Bezic, N. and Dunkic, V. (2001). Localities and seasonal variations in the chemical composition of essential oils of Satureja montana L. and S. cuneifolia Ten, Flavour and Fragrance Journal 16(3): 157-160.

Ph. Jug. IV (1984). Yugoslav Pharmacopoeia IV, Savezni zavod za zdravstvenu zaštitu, Beograd.

Radanovic, D., Markovic, T., Vasin, J. and Banjac, D. (2016). The efficiency of using different mulch films in the cultivation of yellow gentian (Gentiana lutea L.) in Serbia, Ratarstvo i povrtarstvo 53(1): 30-37.

Radanovic, D., Pljevljakusic, D., Markovic, T. and Ristic, M. (2007). Influence of fertilization model and PE mulch on yield and quality of Arnica (A. montana) at dystric cambisol, Zemljište i biljka 56: 85-95.

Rzepa, J., Sajewicz, M., Baj, T., Gorczyca, P., Włodarek, M., Głowniak, K., Waksmundzka-Hajnos, M. and Kowalska, T. (2012). A Comparison of Methodical Approaches to Fingerprinting of the Volatile Fraction from Winter Savory (Satureja montana), Chromatography Research International 2012(2012): 1-8.

Saglam, C., Atakisi, I., Turhan, H., Kaba, S., Arslanoglu, F. and Onemli, F. (2004). Effect of propagation method, plant density, and age on lemon balm (Melissa officinalis) herb and oil yield, New Zealand Journal of Crop and Horticultural Science 32(4): 419-423.

Sefidkon, F., Jamzad, Z. and Mirza, M. (2004). Chemical variation in the essential oil of Satureja sahendica from Iran, Food Chemistry 88(3): 325-328.

Shalaby, A., Khattab, M., El-Gamassy, A. and El-Gamassy, K. (1993). Cultivation of Melissa officinalis in Egypt; 1. Effects of fertilization, spacing and planting season, Acta Horticulturae 331: 115-120.

Shalaby, A. S., El-Gengaihi, S. E., Agina, E. A., El-Khayat, A. S. and Hendawy, S. F. (1997). Growth and Yield of Echinacea purpurea L. as Influenced by Planting Density and Fertilization, Journal of Herbs, Spices E Medicinal Plants 5(1): 69-76.
Slavkovska, V., Jancic, R., Bojovic, S., Milosavljevic, S. and Djokovic, D. (2001). Variability of essential oils of Satureja montana L. and Satureja kitaibelii Wierzb. ex Heuff. from the central part of the Balkan peninsula, Phytochemistry 57(1): 7176.

Slavkovska, V., Jancic, R., Milosavljevic, S. and Djokovic, D. (1997). Variability of the Essential Oil Composition of the Species Satureja montana L. (Lamiaceae), Journal of Essential Oil Research 9(6): 629-634.

Stepanovic, B. and Radanovic, D. (2011). Tehnologija gajenja lekovitog bilja u Srbiji, Institut za proučavanje lekovitog bilja "Dr Josif Pančić".

Ubavić, M Bogdanović, D. and Vojin, S. (2005). Mineralna azotna i organska đubriva kao izvor azota, in K. R (ed.), Azot: agrohemijski, agrotehnički, fiziološki i ekološki aspekti, Naučni institut za ratarstvo i povrtarstvo. 